\title{
MANAGEMENT ELEMENTS FOR TWO ALBURNINAE SPECIES, ALBURNUS ALBURNUS (LINNAEUS, 1758) AND ALBURNOIDES BIPUNCTATUS (BLOCH, 1782) BASED ON A DECISION-SUPPORT SYSTEM STUDY CASE
}

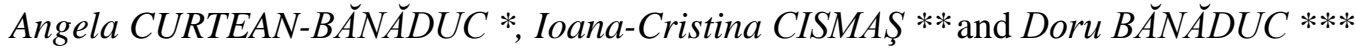 \\ * "Lucian Blaga" University of Sibiu, Faculty of Sciences, Dr. Ion Raţiu Street 5-7, Sibiu, Sibiu County, \\ Romania, RO-550012, angela.banaduc@ulbsibiu.ro \\ ** "Lucian Blaga" University of Sibiu, Faculty of Sciences, Dr. Ion Raţiu Street 5-7, Sibiu, Sibiu \\ County, Romania, RO-550012, cristha_83@yahoo.com \\ *** "Lucian Blaga" University of Sibiu, Applied Ecology Research Center, Dr. Ion Raţiu Street 5-7, \\ Sibiu, Sibiu County, Romania, RO-550012, ad.banaduc@yahoo.com
}

DOI: 10.2478/trser-2019-0014

KEYWORDS: Bleak, Schneider, fish habitat needs, human activities negative effects, conservation management elements.

\section{ABSTRACT}

ADONIS:CE has been used as a base to create a support-system management decision-making model for Alburnus alburnus (Linnaeus, 1758) and Alburnoides bipunctatus (Bloch, 1782) species. Investigation of the habitat necessities and the identification of the necessary elements for a good status of conservation of these two fish species populations has revealed the pressures and threats to these congener species, for which specific management activities have been finally recommended.

ZUSAMMENFASSUNG: Management Elemente für zwei Alburninae Arten, Alburnus alburnus (Linnaeus, 1758) und Alburnoides bipunctatus (Bloch, 1782) anhand einer Fallstudie als Grundlage für ein Management-Entscheidungssystem.

ADONIS:CE wurde für die Entwicklung eines Modells verwendet, das als Grundlage für ein Entscheidungssystems in Managementfragen für die Arten Alburnus alburnus (Linnaeus, 1758) und Alburnoides bipunctatus (Bloch, 1782) dienen soll. Untersuchungen betreffend Habitatansprüche und Feststellung der notwendigen Elemente für einen guten Erhaltungszustand der Populationen dieser Fischarten ließen deutlich die Gefährdungen der beiden verwandten Arten erkennen, für die ein entsprechendes Management vorgeschlagen wird.

REZUMAT: Elemente de management pentru două specii de Alburninae, Alburnus alburnus (Linnaeus, 1758) şi Alburnoides bipunctatus (Bloch, 1782) bazate pe un studiu de caz al unui sistem de suport decizional.

ADONIS:CE a fost utilizat pentru a crea un model de sistem-suport pentru luarea deciziilor de management pentru speciile Alburnus alburnus (Linnaeus, 1758) şi Alburnoides bipunctatus (Bloch, 1782). Investigarea necesităţilor de habitat şi a elementelor necesare pentru un statut bun de conservare al populaţiilor acestor două specii, au relevat presiunile şi ameninţările asupra acestor specii congenere pentru care au fost recomandate în final măsuri specifice de management. 


\section{INTRODUCTION}

Regardless of variation in need and reserve induced by the dynamic of fishing activities results, fish remain a significant source of food in many regions $(*, 2002)$. Fish population management systems, to assure the protein and also the game needs of the humans, need to be complex, innovative, and highly addaptative to the local/regional habitat, biotic and humanrelated conditions (Cochrane, 1999). The increasing desire for more fish protein is evident everywhere, and this threat demands a focused, creative struggle in identifying practical answers for conservative and economic issues (Agnew et al., 2009; Monte-Luna et al., 2016).

Usually only the conservation and high-direct, economic valuable fish species benefit from adapted management plans, and very rarely the indirect economic valuable fish species, which consist the trophic base for upper trophic level fish species (Bănăduc et al., 2011).

Too often, many different fish species, belonging to a certain overspecific taxonomic group with different economic and/or conservation value, are confused by the local fisherman (Oţel, 2007), situations in which a proper conservation is hard to implement and sustain. In some such cases, specific on site and on species adapted management systems can offer integrated management elements, which is the goal of this Târnava Mare River study case.

The Alburninae subfamily (Actinopterygii, Cypriniformes, Cyprinidae) include over eighteen species (Fish Base, 2018) including Alburnus alburnus (Linnaeus, 1758) and Alburnoides bipunctatus (Bloch, 1782). A relatively common fish species in the Târnava Mare River, with relative, similar morphological and colour aspects, these two fish species, especially in young age classes (Bănărescu, 1964, 2005), can be difficult to identify, creating problems in their populations' assessment, monitoring, and management.

The Târnava Mare Basin is a well known area under constant and variable human impact and effects on local biota (Cupșa, 2005; Sîrbu, 2005; Momeu and Péterfi, 2005; Robert and Curtean-Bănăduc, 2005), including species of fish fauna containing Alburnus alburnus and Alburnoides bipunctatus (Bănăduc, 2005; Curtean-Bănăduc, 2005; Păpuc et al., 2017).

There is no general accepted "golden rule" in Carpathian streams and rivers fish populations' optimum management, but it is obvious that one feature is usually correlated with beneficial consequences, namely science-based adequate management, the goal of this study relaying on this specific approach.

In nature conservation, modeling is frequently used to obtain the "large picture" of various systems and/or actions of peculiar domains. The pieces of the modeling process are practical in discriminating the specific phases of adaptive species and their environment management. Using ADONIS:CE, we can construct models that support management objectives. This type of model targets three operational sectors important for environment conservation: 1) to determine the present state, 2) to assess the effects of modifications and 3 ) to suggest actions to improve the actual state in a desired way. Convincingly, diversified diagrams can be developed to highlight management elements (Hall and Harmon, 2005).

\section{MATERIAL AND METHODS}

The researched area, the Târnava River watershed (Fig. 1) is located in the central area of the Romanian Carpathians arch, running off the Transylvania Depression, in precisely its southern sector of the Târnavelor Plateau. With a watershed of $6,157 \mathrm{~km}^{2}$, a length of $249 \mathrm{~km}$ and a falling elevation of about $1,250 \mathrm{~m}$, the Târnava River is one of the main tributaries of the Mureş River, delineating $21 \%$ of its watershed. It is composed of the confluence of Târnava Mare River (3,606 km² watershed surface; $221 \mathrm{~km}$ length) and Târnava Mică River (2,049 km² watershed surface and 191 km length) near Blaj locality. (Tufescu, 1966; Posea et al., 1983) 


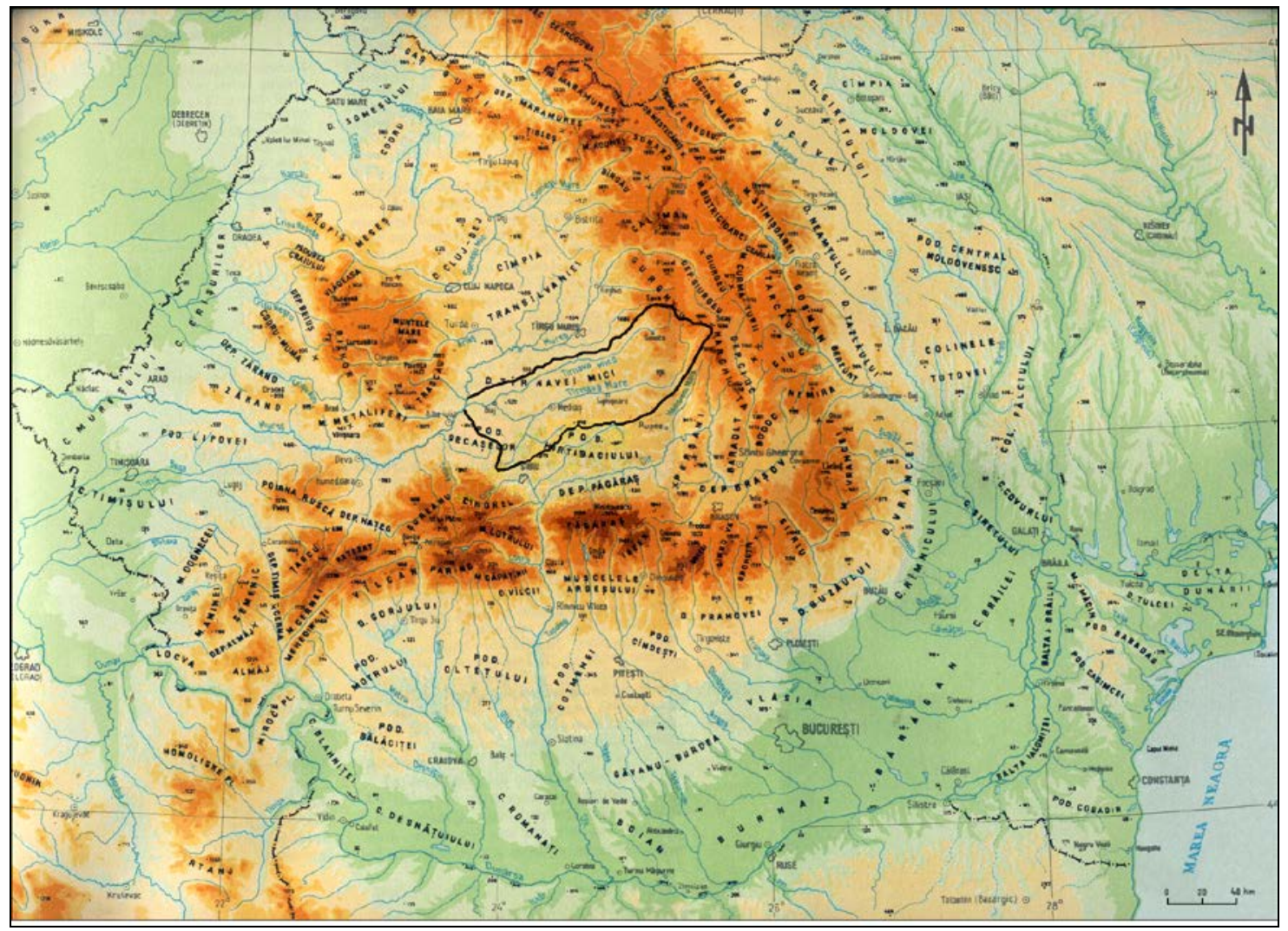

Figure 1: The Târnava River basin location (Bănăduc, 2005).

Alburnus alburnus and Alburnoides bipunctatus are a well known species in Romania (Bănărescu, 1964) with a relatively large distribution in Transylvanian medium and large rivers (Bacalu, 1997; Bănăduc, 1999; Bănărescu et al., 1999; Bănărescu, 2005; CurteanBănăduc and Bănăduc, 2007; Telcean and Cupşa, 2009; Bănăduc et al., 2013, 2014; Bănăduc and Curtean-Bănăduc, 2014; Telcean et al., 2014; Cocan et al., 2015; Păpuc et al., 2017; Stavrescu-Bedivan et al., 2017; Voicu et al., 2016, 2017) where the studied area is located.

These fish species individuals were found for this research and analyzed in Târnava River in 2016; all of them were immediately released alive after an in situ identification, in their natural habitat.

Supplementary reference data for these fish species' presence and ecological status were based on a similar approach study of Bănăduc (2005) and on the local fisherman's captures.

The researched habitat characteristics of the fish populations were evaluated based on specific selected criteria including: population size, size of range, the balanced allocation of fish in age classes, and high/low number of individual fish species individuals in fish communities.

The local lotic habitat necessities, pressures, and threats on the two fish species were studied in connection with their populations' ecological status, the correlations between them and the conservation situation of these species. 
An in situ-on species adaptable management model was projected to build up a suitable management plan that would protect the researched fish species that are living in the studied lotic sectors, with a priority on required processes.

The ADONIS:Community Edition (ADONIS:CE), made-up by the Business Object Consulting (BOC) Group, was applied here. This software is a freely accessible form of ADONIS with few restraints (in comparison with the commercial version). It uses a Business Process Model and Notation (BPMN), a standardized modeling language that supports detectable processes. ADONIS:CE is typically used as an access point to Business Process Management. These processes can be modeled using compatible notation.

\section{RESULTS AND DISCUSSION}

The study results reveal that the main common threats on Alburnus alburnus and Alburnoides bipunctatus fish species are: modifying and fragmentation of specific habitats, water pollution, and overfishing and poaching.

\section{Identified specific requirements}

Both the juveniles and adults need a significant/close to natural water flow and relatively high depths of the water (minimum $0.5 \mathrm{~m}$ ), with rocky-sandy substrata, variable speed of the water flow, and not abundant aquatic vegetation.

\section{Proposed specific habitat indicators}

In the studied lotic sectors, principal habitat indicators as causes for the presence/absence and abundance of Alburnus alburnus and Alburnoides bipunctatus are: average water flowing surface speed (proportion $50 \%$ of the river), relatively slow water flowing surface speed (proportion $50 \%$ of the river), mixed sandy with rocky substrata (50\% of the river), and water surface with relatively high depth of the water ( $50 \%$ of the river).

\section{Management measures}

Management characteristics have been a suggestion for analytical research and, a request for managers which face many pressures and threats on lotic systems. As a result, there are many viewpoints and models which fluctuate based on source, system, and design intricacy. The management indicators can be match based on a process which includes six levels (Krause and Mertins, 1999): designing a process value chain model, determining the key success factors, giving the description of the performance indicators, data acquiring and checking, assessment of the performance indicators, and putting into action process.

This pathway based on a model is sustained by the learning process which appears while realising the process maps; and set up the need for management elements grouped around the record sheets of management measures. It is meaningful to highlight that constructing the essentiality to identify an indicator set for assessment of an entity's overall achievement, the proposed model find the preeminent value delivery process, to which an indicator set for process assessment can be designated, which are generated by diagnosing the success factors for the process and for the entity's performance (Miricescu, 2011, 2014).

Appropriately with this model, we propose that the main management measures include the conservation of: the natural morphology of the lotic systems - natural dynamic of banks and water flow regime; rocky-sandy substratum and relatively deep water depth; the forbiddance of the disposing of wastes in water and on the banks; keeping a medium level of the water including in drought periods based on avoiding of important water removals and use; decreasing water pollution; and implementation of a long term monitoring system for fish. 


\section{Adjusted model for the site management}

The proposed model of the two species of fish Alburnus alburnus and Alburnoides bipunctatus uses common objects of the ADONIS:CE for modeling business processes (BPM), namely: the beginning of the process $(\triangle)$, activities $(\square)$, decisions $(\triangle)$, parallelism $(\triangleleft)$ and merging $(\triangleright)$ - in the case of parallel activities, notes $(\square)$, subprocesses $(\Delta)-$ processes that are used within the basic process, variables ( $\bullet$ and generators ( 4 ) - are used to highlight the percentage of achievement of the habitat indicators (the percentage indicators that ensure conservation status) and the end of the process ( $O$ ).

To better visualize the model structure proposed for the two fish species, figure 2 highlights the inter-model references between processes modeled.

\begin{tabular}{|c|c|c|c|}
\hline \multicolumn{4}{|c|}{ Explorer - Hierarchy } \\
\hline 圂它虽 & $\infty$ घै (ด) & $\underline{\underline{4}} \div$ & (6) \\
\hline
\end{tabular}

Figure 2: Hierarchy of modeled process and inter-model references.

\section{Model description}

The basic process of these two fish species modeled (Fig. 3) is conceived as a description of them, being presented with the help of the following activities: the habitat type, the specific identified requirements (these were modeled with the help of parallelism and merging - independent activities), continues with the "Habitat indicators of Alburnus alburnus and Alburnoides bipunctatus species" subprocess call (Fig. 4), then follows another two activities field observations, pressures and threats on the habitat, and implicitly, on the species Alburnus alburnus and Alburnoides bipunctatus and the process ends. With the help of notes, it was possible to graphically exemplify the characteristics of certain process activities.

The "Habitat indicators of Alburnus alburnus and Alburnoides bipunctatus species" subprocess (Fig. 4) have the same characteristics as a process and contain the specific habitat indicators - proposed for this research, the decisions for verifying them - whether or not they ensure the favourable conservation status of the studied two species Alburnus alburnus and Alburnoides bipunctatus, the management measures to be taken (subprocess - Fig. 5) and the final activity, the implementation of a long-term fish species monitoring system.

For example, the model begins with the first indicator ("Average water flowing surface speed" - proportion $50 \%$ of the river), and the first decision verifies whether it does or does not meet fair conservation status (basically, this was compared to the current state of the indicator - resulting from field measurements - with favourable conservation status).

If for this indicator, the favourable conservation status is fulfilled (the "YES" branch of the decision, variable: Water_flowing_surface_speed = "Yes", probability: 99\%), then the model continues with the second indicator. If the first indicator does not fulfil the favourable conservation status (the "NO" branch of the decision, variable: Water_flowing_surface_speed = "No", probability: $1 \%$ ) then, the model continues with the management measure subprocess - goes through every measure - after which, it returns to the first indicator, and once again checks (after the management measures applied) whether or not the fair conservation status is fulfilled. A loop is formed and the process does not go through the other indicators unless the current indicator meets that condition. 


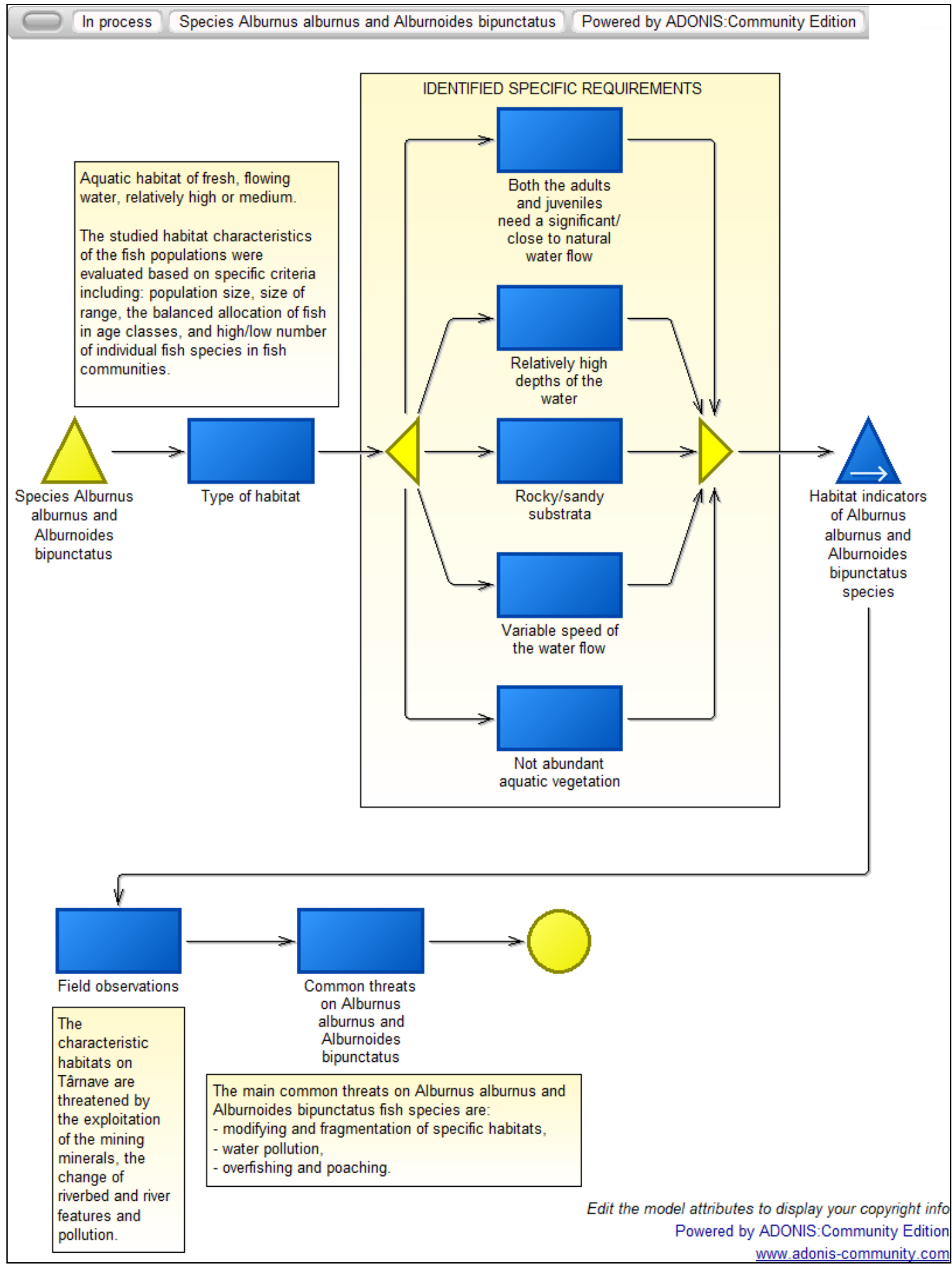

Figure 3: Species Alburnus alburnus and Alburnoides bipunctatus

- critical requirements of habitat. 


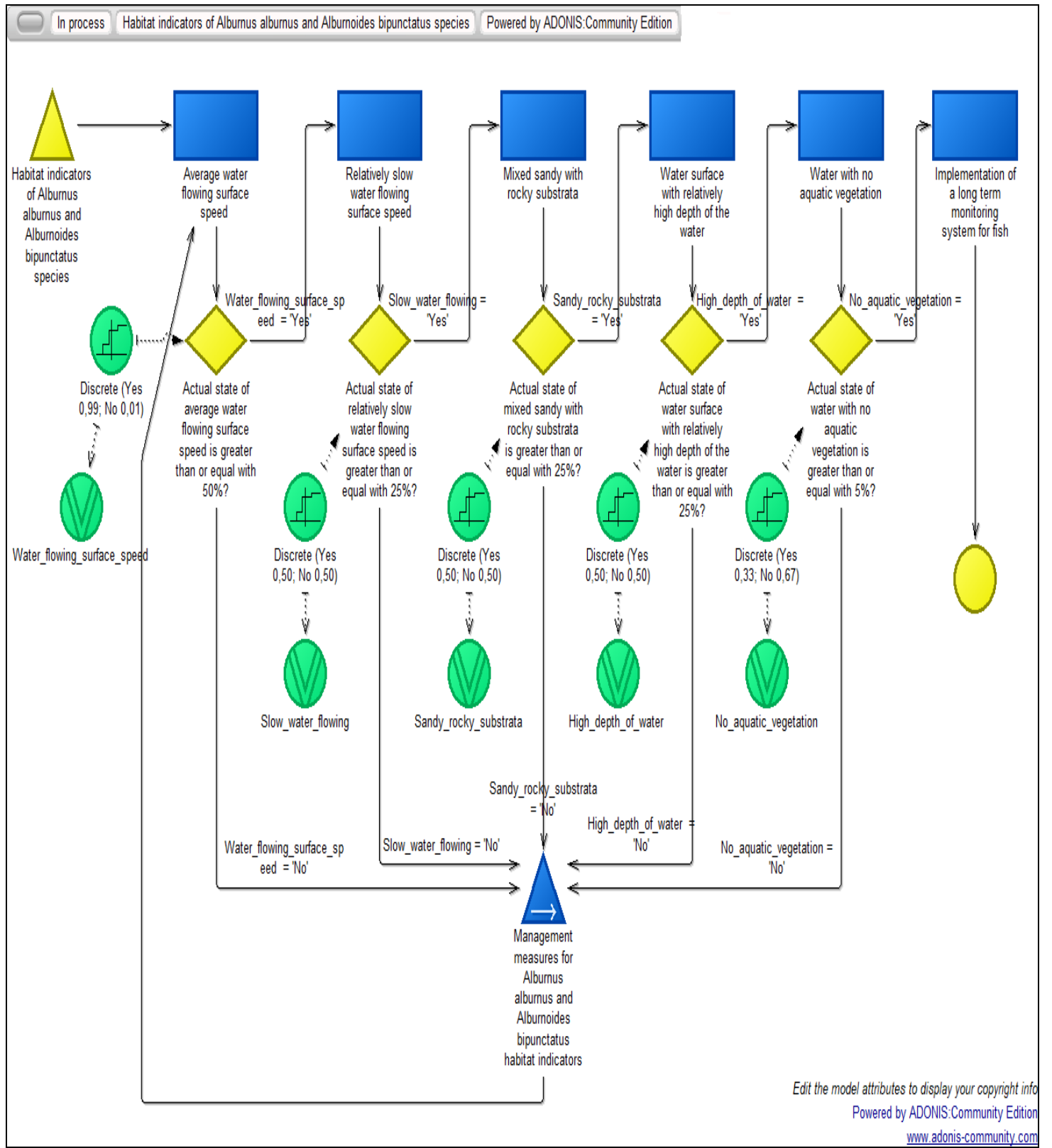

Figure 4: Habitat indicators of Alburnus alburnus and Alburnoides bipunctatus species.

The last subprocess shows the management measures (Fig. 5) model made only with activities. Here are the management measures that should be taken to ensure that the Alburnus alburnus and Alburnoides bipunctatus species preserve their favourable conservation status. Among these, we mention the conservation of the natural morphology of the lotic systems, the preservation of the rocky and sandy substrate, the prohibition of the discharge into the rivers of any type of waste, the maintenance of a medium level of water during periods of drought. 


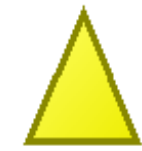

Management

measures for

Alburnus

alburnus and

Alburnoides

bipunctatus

habitat indicators
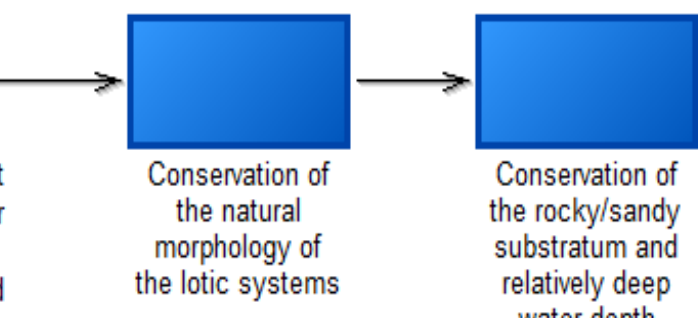

Conservation of the rocky/sandy substratum and relatively deep water depth

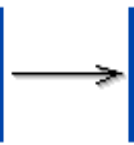

The forbiddance of the disposing of any category of waste in water and on the banks

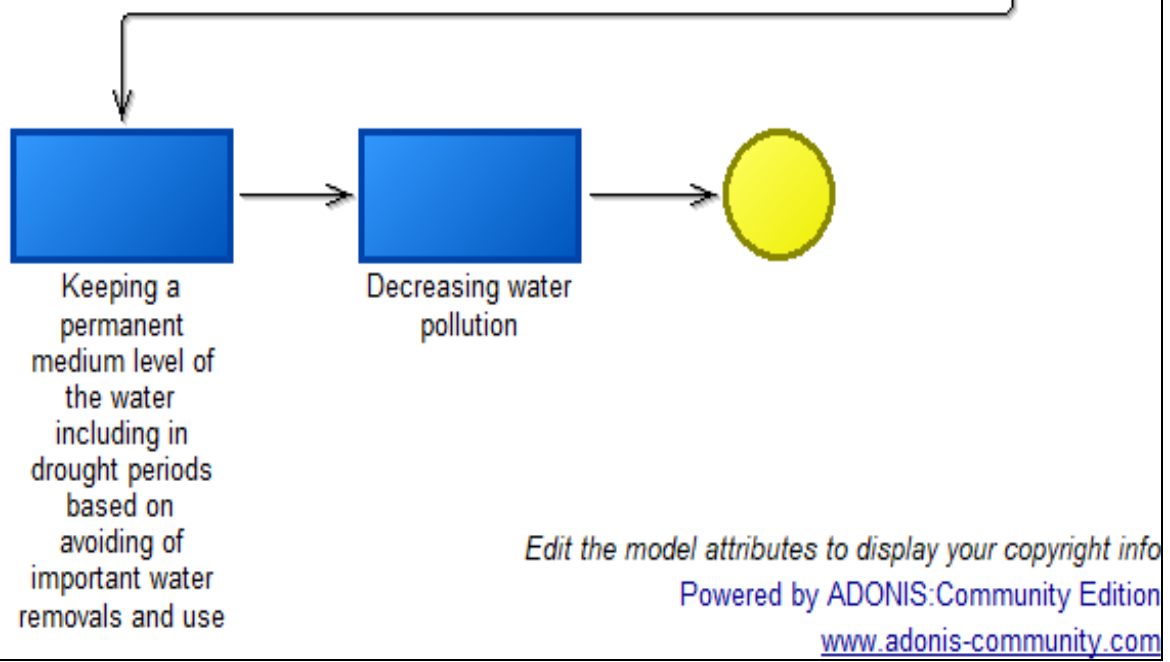

Figure 5: Management measures for Alburnus alburnus and Alburnoides bipunctatus habitat indicators.

\section{CONCLUSIONS}

The principal recorded pressures and threats to the fish species Alburnus alburnus and Alburnoides bipunctatus in the studied lotic sectors of the Târnava Watershed were the following: modifying and fragmentation of characteristic lotic habitats, water pollution, and overfishing and poaching.

Critical for Alburnus alburnus and Alburnoides bipunctatus fish species conservation are the following: the characteristic/natural riverbed morphodynamics guardianship, the diminishment of the existing flowing water habitats fragmentation, the prohibition of riverbed heavy exploitation, the riverine vegetation preservation, the ecological restoration of the riverbeds' characteristic morphodynamic, complex waste management, reducing water pollution, effective poaching restriction, and the creation of an integrated monitoring system where the fish fauna is a core element.

In this particular research, a necessary model for decisions in management in order to back the two Alburninae species was produced, ready to be implemented in the researched area. 
The ADONIS:CE was used here for fish conservation in an area of concern, coming up with a specific management model for Alburnus alburnus and Alburnoides bipunctatus fish species that contain their main necessities regarding the habitat, and the elements that reveal a good ecological status. The suggested management elements help to prevent and/or diminish the identified pressures and negative effects on these species' populations.

This particular on-site, on habitats and on species management decisions supporting model scheme for Alburnus alburnus and Alburnoides alburnoides, will be more effective if integrated in a management model for the Târnava Watershed fish associations. 


\section{ACKNOWLEDGEMENTS}

The authors wish to thank Mr. Popa E. M. for his continuous support in informatics and to many fishers of the Târnava Basin for their help during the research. This study data was acquired in the period of the projects POS Mediu, priority ax four project code SMIS CSNR 17049 "Pentru Comunităţi Locale și Natură - Bazele managementului integrat Natura 2000 în zona Hârtibaciu - Târnava Mare - Olt (PH+ PRO MANAGEMENT Natura 2000)" and Project ID 66243, SIDPOP - "Instrument suport pentru luarea deciziilor în domeniul managementului poluanţilor organici persistenţi. Studiu de caz: Bazinul hidrografic Mureş", finanţat în cadrul programului R004 - „Reducerea substanţelor periculoase, prin Mecanismul Financiar al Spaţiului Economic European (SEE)”. 


\section{REFERENCES}

1. Agnew D. J., Pearce G., Peatman T., Watson R., Beddington J. R. and Pitcher T., 2009 Estimating the worldwide extent of illegal fishing, PloS ONE, 4, e4570.

2. Bacalu P., 1997 - The fish fauna of the Iza River, Maramureș (Romania), Travaux du Muséum National d'Histoire Naturelle “Grigore Antipa”, XXXVII, 205-212.

3. Bănăduc D., 1999 - Data concerning the human impact on the ichthyofauna of the upper and middle sectors of the Olt River, Transylvanian Review of Systematical and Ecological Research, 1, Edit. Universităţii “Lucian Blaga” din Sibiu, ISBN 973-9410-69-3, 157-164.

4. Bănăduc D., 2005 - Fish associations - habitats quality relation in the Târnave rivers (Transylvania, Romania) ecological assessment, Transylvanian Review of Systematical and Ecological Research, 2, The Wetlands Diversity, 123-136.

5. Bănăduc D., Oprean L. and Bogdan A., 2011 - Fish species of community interest management issues in Natura 2000 site Sighişoara-Târnava Mare (Transylvania, Romania), Revista Economică 3, 56, econ.ulbsibiu.ro, Crises after crisis inquiries from a national, European and Global perspective, II, 23-27, ISBN 978-606-12-0139-6.

6. Bănăduc D., Stroilă V. and Curtean-Bănăduc A., 2013 - The fish fauna of the Timiş River (Banat, Romania), Transylvanian Review of Systematical and Ecological Research, 15, special issue The Timiş River Basin, Edit. Universităţii "Lucian Blaga” din Sibiu, ISSN 1841-7051, 145-172.

7. Bănăduc D. and Curtean-Bănăduc A., 2014 - The "Porţile de Fier/Iron Gates" Nature Park (Romania) some Danube northern tributaries fish fauna, Transylvanian Review of Systematical and Ecological Research, 16, special issue The "Iron Gates” Natural Park, Edit. Universităţii "Lucian Blaga” din Sibiu, ISSN 1841-7051, 165-170.

8. Bănăduc D., Curtean-Bănăduc A., Lenhardt M. and Guti G., 2014 - "Porţile de Fier/Iron Gates” Gorges area (Danube) fish fauna, Transylvanian Review of Systematical and Ecological Research, 16, special issue The "Iron Gates" Natural Park, Edit. Universităţii "Lucian Blaga" din Sibiu, ISBN 1841-7051, 171-196.

9. Bănărescu P. M., 1964 - Fauna Republicii Populare Române, Pisces-Osteichthyes (Pești Ganoizi și Osoși), XIII, Edit. Academiei Republicii Populare Române, 959. (in Romanian)

10. Bănărescu P. M., 2005 - Ichthyological investigations in the drainage area of the Mureș River, 1948-1997, Transylvanian Review of Systematical and Ecological Research, 2, The Târnava River Basin, 137-144.

11. Bănărescu P., Telcean I., Nalbant T., Harka A. and Ciobanu M., 1999 - The fish fauna of the River Someş/Szamos basin, The Someş River valley, Sarkany-Kiss A. and Hamar J. (eds), Szolnok-Szeged-Târgu Mureș, Tiscia-Monograph series, 229-233.

12. Cocan D., Popescu F., Laţiu C., Coşier V., Coroian V., Negrea O., Ihuţ A. and Mireşan I., 2015 - Meristic and morphometric characteristics of Spirlin, Alburnoides bipunctatus Bloch 1782 (Actinopterygii: Cyprinidae) of the Letca Area - Someş River, Bulletin UASVM animal Science and Biotechnologies, 72, 2, DOI:10.15835, 252-254.

13. Cochrane K. L., 1999 - Complexity in fisheries and limitations in the increasing complexity of fisheries management, ICES Journal of Marine Science, 56, 6, 917-926.

14. Cupşa D., 2005 - Preliminary note on the aquatic Oligochaeta from the Târnave rivers, Transylvanian Review of Systematical and Ecological Research, 2, The Wetlands Diversity, 43-50.

15. Curtean-Bănăduc A., 2005 - Study regarding Târnava Mare and Târnava Mică rivers (Transylvania, Romania) stonefly (Insecta, Plecoptera) larvae communities, Transylvanian Review of Systematical and Ecological Research, 2, The Wetlands Diversity, 75-84.

16. Curtean-Bănăduc A. and Bănăduc D., 2007 - Benthic macro-invertebrate and fish communities of some southern Târnava Mare tributaries (Transylvania, Romania), Transylvanian Review of Systematical and Ecological Research, 4, The Saxon Villages Region of southeast Transylvania, Edit. Universităţii “Lucian Blaga” din Sibiu, ISSN 1841-7051, 135-148. 
17. Fish Base, 2018 - https://www.fishbase.de/

18. Hall C. and Harmon P., 2005 - The Enterprise Architecture, Process Modeling and Simulation Tools Report, Version 1.1 November.

19. Krause O. and Mertins K., 1999 - Performance management, in Mertins K., Krause O. and Schallock O., Global Production Management, Proceedings of the IFIP, WG5.7, International Conference on Advances in Production Management Systems, September, 243-251.

20. Miricescu D., 2011 - Study on temporal influences on management and managers of business organizations, Proceedings of RMEE, Todesco Publising House, 479-490.

21. Miricescu D., 2014 - Semnele şi amprenta timpului asupra managementului contemporan, Edit. Universităţii “Lucian Blaga" din Sibiu, Sibiu, 69-88. (in Romanian)

22. Momeu L. and Peterfi L. Ş., 2005 - The structure of Diatom communities inhabiting the Târnava Mică and Târnava Mare rivers, Transylvanian Review of Systematical and Ecological Research, 2, The Wetlands Diversity, 5-12.

23. Monte-Luna P., Lluch-Belda D., Arreguin-Sánchez F., Lluch-Cota S. and Villalobos-Ortiz H., 2016 - Approaching the potential of world marine fish, Transylvanian Review of Systematical and Ecological Research, 18.1, 45-56.

24. Oțel V., 2007 - Atlasul Peștilor din Rezervația Biosferei Delta Dunării, Edit. Centru de Informare Tehnologică Delta Dunării, Tulcea, ISBN 978-973-88117-0-6, 481.

25. Păpuc T., Cocan D., Lațiu C., Uiuiu P. and Mireșan V., 2017 - Morphometric differences of Spirlin, Alburnoides bipunctatus Bloch, 1782 from the major catchments of Transylvania, Bulletin of University of Agricultural Sciences and Veterinary Medicine Cluj-Napoca, Animal Science and Biotechnologies, 74, 2, 177-184.

26. Posea G. (coord.), 1983 - Enciclopedia Geografică a României, Edit. Știinţifică şi Enciclopedică, București, 847. (in Romanian)

27. Robert S. and Curtean-Bănăduc A., 2005 - Aspects concerning Târnava Mare and Târnava Mică rivers (Transylvania, Romania) caddis fly (Insecta, Trichoptera) larvae communities. Transylvanian Review of Systematical and Ecological Research, 2, The Wetlands Diversity, 89-98.

28. Sîrbu I., 2005 - The freshwater molluscs from the Târnava rivers basin (Romania), Transylvanian Review of Systematical and Ecological Research, 2, The Wetlands Diversity, 2005, 51-60.

29. Stavrescu-Bedivan M.-M., Aioanei F. T. and Vasile Scăețan G., 2017 - Length-weigth relationships and condition factor of 11 fish species from the Timiş River, Western Romania, Agriculture and Forestry, Podgorita, 63, 4, 281-285.

30. Telcean I. C. and Cupşa D., 2009 - Fishfauna from the lowland Mureş River (Romania) and the floodplain natural park area (Western Romania), Analele Universităţii din Oradea, Fascicula Biologie, XVI, 1, 131-135.

31. Telcean I. C., Cupşa D., Sas-Kovács I., Cicort-Lucaciu A. S., Covaciu-Marcov S. D., 2014 Some data upon the fish fauna from Carei Plain natural protected area obtained with herpetological methods, North Western Journal of Zoology, 10, Supplement 1, 135-140.

32. Tufescu V., 1966 - Subcarpaţii şi depresiunile marginale ale Transilvaniei, Edit. Ştiinţifică, 1966, Bucureşti. (in Romanian)

33. Voicu R., Urbani J. and Bretccan P., 2016 - Fish migration over a wooden discharge sill located on the Bistra Mărului River, 303-308, in Gâştescu P. and Breţcan P. (eds) 2016 - Water resources and wetlands, http://www.limnology.ro/wrw2018/proceedings.html

34. Voicu R., Voicu L., Curtean-Bănăduc A. and Bănăduc D., 2017 - Restoring the fish fauna connectivity of the Hârtibaciu River - Retis Dam study case (Transylvania, Romania), Acta Oecologica Carpatica, X.II, 73-86.

35. *, 2002 - The state of the world fisheries and aquaculture 2002, Rome, Food and Agriculture Organization of the United Nations. 